\title{
Legal Aid Online Application for People with Disabilities - Opportunities and Challenges
}

\author{
Rosmalinda ${ }^{1, *}$ Ningrum Natasya Sirait ${ }^{2}$, Ade Candra ${ }^{3}$.
}

\author{
${ }^{1}$ Universitas Sumatera Utara \\ ${ }^{2}$ Universitas Sumatera Utara \\ ${ }^{3}$ Universitas Sumatera Utara \\ Email: rosmalinda@usu.ac.id
}

\begin{abstract}
Indonesia has ratified the Convention on The Rights of Persons with Disabilities (CRPD) through Law No. 19/2011 in the same year when Law No. 16/ 2011 concerning Legal Aid was legalized too. Although there are two Laws which concerns on People with disabilities (PwDs), they still face problems to access legal justice. This study withdraw the legal opportunity and chalengging in developing an Android Applications for Legal Aid Services for. The study used a normative juridical approach by analyzing regulations related to PwDs. It also did asurvey which involved PwDs in Medan, Binjai and Deli Serdang Districts of North Sumaetra Province. This study found that (1) the rules have accommodated the provision of legal aid to PwDs; (2) there are some challenges in developing an android application to provide online legal aid for PwDs which is not available yet. As conclusion, in order to fullfill PwDs rights in access to justice, it is a must to provide an easy and cheap facility to access legal aid such as an android application. As suggestion, it is necessary to develop an android application for legal aid for PwDs.
\end{abstract}

Keywords: Application, Android, Legal Aid, PwDs

\section{INTRODUCTION}

Legal aid, legal service and legal assistance are terms which used in access to justice especially for poor community.[1] Furthermore, the provision of legal aid is a form of law enforcement efforts by defending the interests and human rights of the poor.[1] The purpose of providing legal aid to ensure the right of all people to obtain legal advice.[2]

As a legal state, Indonesia ensure the rights of its citizens in the provision of legal aid since beginning through Constitution-1945. In the Preamble section and Article 28 D paragraph (1) provide guarantees for fair recognition, guarantees, protection and legal certainty and are entitled to equal treatment before the law. Since, it is a state rules, it applies to every person including PwDs.[3]

Indonesia has ratified the Convention on the Rights of PwDs (CRPD) through Law No. 19/2011. It is in the same year Indonesia Legalized Law No 16/2011 regarding Legal Aid. It seems that Indonesia answer the question concerning Non-discrimination principle for every Indonesian citizen towards access to justice without exception based on the economy.[4] Not only Article 1 point 1 , but also Article 4 of the Law emphasizes the scope of legal assistance that must be provided related to legal issues, namely (a) civil, (b) criminal, and (c) state administration, both litigation and non-litigation.[4] Internationally, the ratification of the CRPD has provided legal certainty in terms of protection in the judicial process involving persons with disabilities, to access justice but this group is still in the last position to enjoy it.[5]

Law No 19/ 2011 concerning ratification on Convention on The Rights PwD already regulated on legal protection regarding the rights of PwD. It mentiones several fundamental principles, namely:

1. Respect for inherent dignity, individual autonomy, including freedom of choice and individual independence;

2. Non-discrimination;

3. Full and effective participation and participation in society;

4. Respect for differences and acceptance of disability as part of human diversity and humanity

5. Equality of opportunity

6. Accessibility 
7. Equality between sex

8. Respect for the growing capacity of children with disabilities and respect for the rights of children with disabilities to maintain their identity.

Ratifying an international convention does not mean PwDs are easy to access to justice. There are still many cases where PwDs have not received proper treatment in court. It is not only related to physical facilities that were built without considering the interests of persons with disabilities to move but also law enforcement officers who behave unfriendly.[6]

Legal assistance for persons with disabilities still encounters obstacles, sucah as (a) in communication, (b) limited human resources, (c) lack of budget availability to serve persons with disabilities, and (d) family are neglected the need of legal assistance for PwD.[7]

In particular, access to justice for persons with disabilities is related to legal assistance.[8] Access of PwDs to Legal Aid Providers facing challenges, including (a) the distance-from their house to the Legal assistance provider location which known as legal Aid Institution-Organisasi Bantuan Hukum (OBH), (b) The cost is expensive which cover accomodation and transportation, (c) lack of information concerning $\mathrm{OBH}$, (d) Limited number of $\mathrm{OBH}$, (e) uneven distribution of OBH.[8]

Based on the description above, this study would describe the development of legal aid arrangements in Indonesia regarding the fulfillment of the right to justice. In particular the study will find legal opportunities for PwDs to access legal assistance using the Android application.

\section{METHODOLOGY}

This study analyzes 4 regulations related to legal aid services; (a) Law No. 16/2011 concerning Legal Aid, (b) Government Regulation No. 42/2013 concerning Terms and Procedures for Providing Legal Aid and Distribution of Legal Aid Funds, (c) Regulation of the Minister of Law and Human Rights No. 3 of 2013 concerning Procedures for Verification and Accreditation of Legal Aid Institutions or Community Organizations (d) Regulation of the Minister of Law and Human Rights Number 4 of 2021 concerning Legal Aid Service Standards. This study also conducted a survey to $\mathrm{OBH}$ who provided legal service for PwD, Institutions which concerns on PwDs and PwDs in Medan, Deli Serdang and Binjai.

\section{RESULT AND DISCUSSION}

\subsection{Legal opportunity concerning online legal aid}

It needs times to the fulfillment of PwDs' righst. Indonesia needed almost 5 years to have special policies related to PwDs. All matters related to disability are then accommodated through Law Number 8/2016 concerning PwD. Article 29 states that the government and local governments are obliged to provide such legal assistance.[9] North Sumatera for instance is still drafting its local regulation concerning Legal aids which of course will included PwDs. to ensure the implementation of the provisions of article 27 paragraph (3) of Law 8/2016, the Government of Indonesia issued Government Regulation Number 70 of 2019 concerning the Planning, Implementation, and Evaluation of the Respect, Protection and Fulfillment of the Rights of PwD.

In the Master Plan for PwDs states that there are 7 (seven) strategic targets which are expected to gradually cover all aspects to realize respect, protection, and fulfillment of the rights of PwDs, one of the strategic targets is the protection of rights and political access and justice for PwDs. One of the policies formulated to guarantee it is the Protection of PwDs from violence and exploitation, and neglect in the judicial process and the stages of implementing appropriate decisions for PwDs.

The implementation strategy is through (a) Developing examination standards that include the qualifications of Public Prosecutors, investigators, judges, correctional officers, disability assistants, legal assistants, advocates and interpreting procedures, examination procedures; as well as proper facilities and services for the judiciary for persons with disabilities (b) Conducting education to law enforcement officers regarding legal aid providers regarding the implementation of handling cases involving Persons with Disabilities (c) Developing standards and mechanisms for monitoring the fulfillment of the rights of PwDs who are in conflict with the law.

This Government Regulation is a development of guarantees for the fulfillment of the rights of PwDs to access legal aid services. Previously, Law Number $12 / 2005$ concerning Ratification of the International Covenant on Civil and Political Rights specifically mentions it in Article 19 Article 14, paragraph 3(d).

Figure 1. Schematic of the Development of Legal Aid Services Regulations in favor of Persons with Disabilities

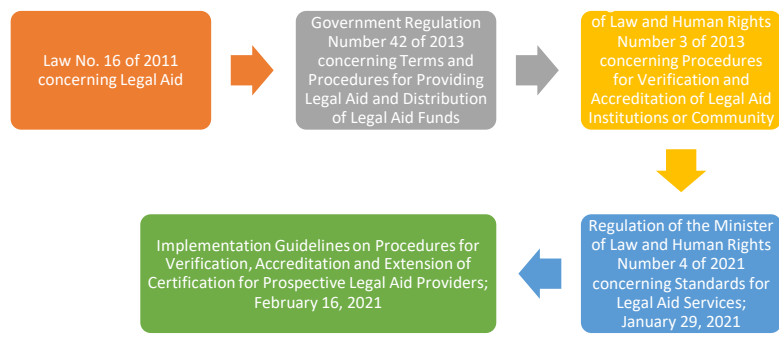

The scheme above shows that the arrangement of legal aid for PwDs is regulated in Law No. 16 of 2011 concerning Legal Aid. The important point of the regulation in this Law is that the allocation of legal aid is only based on the economic level with the mention of the 
allocation of legal aid for the poor. As a group of people with special needs, legal aid services provided to PwDs needs special treatments in order to fulfill their rights.[3]

Furthermore, Regulation of the Minister of Law and Human Rights Number 10 of 2015 concerning Implementing Regulations of Government Regulation Number 42 of 2013 concerning Terms and Procedures for Providing Legal Aid and Distribution of Legal Aid Funds as amended by Regulation of the Minister of Law and Human Rights Number 63 of 2016 concerning Amendments to Regulation of the Minister of Law and Human Rights Number 10 of 2015 concerning Implementing Regulations of Government Regulation Number 42 of 2013 concerning Terms and Procedures for Providing Legal Aid and Distribution of Legal Aid Funds.

In the Regulation of the Minister of Law and Human Rights Number 63 of 2016 it is stated in Article 34 paragraph 1(c) that the application for legal aid as referred to must attach a certificate of poverty from the lurah, village head or official at the same level as the domicile of the applicant for legal aid. This certificate "often" becomes an obstacle for applicants for legal aid, so an alternative is given to replace the poor certificate as referred to in paragraph 2 which known as Indonesian Cards in various objectives, namely: (a) public health insurance, (b) direct cash assistance, (c) prosperous family, (d) rice for poor, (e) Indonesian Smart; (f) Indonesian Healthy; (g) Social protection; (h) other government welfare program membership documents; or (i) other documents which stated the economic status.

There are 3 important things that become the focus of discussion in seeing opportunities for legal arrangements regarding Legal Aid Services for PwDs, namely (a) Definition of Legal Aid; ((b) Legal Aid Providers, and (c) Legal Aid Recipients. Specifically, the definition of legal aid has not changed in this instrument, namely legal services provided by legal aid providers free of charge to legal aid recipients. The definition of legal aid providers is Legal aid agencies or community organizations that provide legal aid services based on Law No. 16 of 2011 concerning Legal Aid Recipients of legal aid are poor people.

Minister of Law and Human Rights Regulation Number 3 of 2013 concerning Procedures for Verification and Accreditation of Legal Aid Institutions or Community Organizations is an arrangement based on the provisions of Article 7 paragraph (4) of Law Number 16 of 2011 concerning Legal Aid. In Article 1 point 4 it is stated that the recipients of legal aid are poor people or groups of people.

Recipients of legal aid are poor people or groups of people, which is a must as stated in the Implementing Instructions. Regulation of the Juklak on Procedures for Verification, Accreditation and Extension of
Certification for Prospective Legal Aid Providers issued by the Ministry of Law and Human Rights No: PHNHN.04.03-14 dated February 16, 2021 states that Legal Aid Providers and Legal Aid Organizations must have evidence implementation of legal aid for litigation cases and non-litigation activities for the poor.

The situation and condition of legal aid requirements that require that it be given only to people or to poor groups is reaffirmed in Article 1 point 7 of the Regulation of the Minister of Law and Human Rights Number 4 of 2021 concerning Legal Aid Service Standards. The bright point of justice in access to legal aid is illustrated in Articles 2 and 3. These two articles mention guaranteeing the quality of legal aid services, the minister stipulates "Strala bankum" which is an abbreviation of Standar Layanan Bantuan Hukum-Standard of Legal Service Aid. In Article 3 paragraph 2 (b) it is stated that in the context of implementing the Bankum Starla, the legal aid provider is obliged to assess the condition of vulnerability and legal needs of the legal aid recipient related to the problems faced.

The provisions of Article 3 paragraph (2) letter b provide an opportunity to expand the meaning or understanding of the word poor person or group of people. The need for this assessment is continued in Article 4 paragraph 2 which reads "In the context of implementing Starla Bankum, Legal Aid Recipients are obliged to: (a) be cooperative and communicative in assisting the handling of cases; (b) follow the rules and regulations determined by the Legal Aid Applicant; and (c) provide honest and complete data, information, information, and copies of documents related to the legal issues faced." This policy takes effect in August 2021, which is 6 months from the date of promulgation (February 3, 2021).

PwDs are one of the parties entitled to receive legal assistance. Based on Article 5 of Law Number 16 of 2011 concerning Legal Aid states that "the recipient of legal aid is every person or group of poor people who cannot fulfill basic rights properly and independently".[10] Article 4 of Law Number 16 of 2011 states that the scope of legal aid includes legal assistance provided to legal aid recipients who are facing legal problems, legal assistance provided includes civil, criminal, and state administrative legal issues, both litigation and non-litigation and assistance The law given includes exercising power of attorney, accompanying, representing, defending, and/or taking other legal actions for the legal interest of the recipient of legal aid.[10]

Internationally, there is United Nations Principles and Guidelines on Access to Legal Aid in Criminal Justice Systems, adopted by the United Nations General Assembly in December, 2012 which mentions 14 principles and 18 guidelines. The existence of this rule is in accordance with Indonesia which has Law No. 16 of 2011 concerning Legal Aid; article 7 paragraph (3), it 
needs to be verified and accredited for Legal Aid Institutions/Organizations that are eligible to become Legal Aid Providers and can access budgets from central and local governments.

Based on the description above, it shows that the concept of structural legal aid is an activity that aims to create conditions for the realization of a law that is able to change the unequal structure towards being equal among persons.[2] The principle of non-discrimination must be applied because Referring to the description above, persons with disabilities are included in groups or people who are entitled to receive legal assistance.[2]

\subsection{Challenges in Legal Aid implementation}

In the previous section it was discussed that several regulations in Indonesia regarding legal aid and persons with disabilities have provided opportunities for the development of online legal aid for persons with disabilities. In 2021; Instructions for the implementation of Regulation of the Minister of Law and Human Rights Number 3 of 2013 is regulated in The Ministry of Law and Human Rights of the Republic of Indonesia National Legal Development Agency Implementation Guidelines on Procedures for Verification, Accreditation, and Extension of Certification for Prospective Legal Aid Providers Number: PHN-HN.04.03-14;

The Important points in the verification and accreditation legal aid organisations related with online legal aid for PwDs is stated in Chapter VI concerning Accreditation which classifying $\mathrm{OBH}$ based on;

1) the number of litigation cases handled related to the poor;

2) the number of non-litigation activities handled related to the poor;

3) the number of advocates;

4) the number of paralegals;

5) the number of administrative staff who understand information technology;

6) the formal and non-formal education of advocates and paralegals;

7) experience in handling or providing legal assistance;

8) the scope of case handling;

9) ownership status and office infrastructure,

10) period of establishment of $\mathrm{OBH}$;

11) Basic and Operational rules (AD/ART) of OBH;

12) financial statements in accordance with accounting standards;

13) Tax Number of OBH; and

14) availability of Internet network at $\mathrm{OBH}$

In the period of 2019-2021, there are 524 accredited legal aid provider in Indonesia. In detailed, there are 21 Legal aid provider in Aceh; 32 in North Sumatera and 57 in Middle Java.
Regulation of the Supreme Court number 1 of 2014 concerning Guidelines for Providing Legal Services for Poor People in Court. Letter of Director General of the General Judiciary Agency Number 52/DJU/SK/HK.006/5/2014 concerning the implementation guidelines for the Regulation of the Supreme Court of the Republic of Indonesia Number 1 of 2014 concerning guidelines for the provision of legal services for underprivileged communities in court. Letter of the Director General of the General Judiciary Agency Number 3/DJU/HM02.3/6/2014 concerning Information Technology-Based Court Administration in the General Courts. Posbakum (Pos Bantuan HukumLegal Aid Desk) Electronic on websites as seen at District Court in Tahuna-Sangihe island-North SulawesiIndonesia.

The findings of this study further strengthen how legal arrangements in Indonesia have provided opportunities for the availability of online legal aid. As befits a program, when there are opportunities, there are challenges. This study found several challenges related to the implementation of legal aid, especially in the form of online application development.

First, the variety of Persons with Disabilities includes: (a) Physical; (b) Intellectual; (c). mental; and/or (d). sensory disabilities; (e) The variety of PwDs as referred to singly, multiplely, or multiple times for a long period of time determined by medical personnel in accordance with the provisions of the legislation.[11] This diversity poses challenges related to the priority of users of online legal aid applications because diversity in disability means having a variety of needs.

Second, the low need for persons with disabilities to access assistance, especially legal assistance to $\mathrm{OBH}$ or legal aid providers. Based on a survey that was openly submitted to persons with disabilities after conducting a pilot test of the question guide to: (a) Legal Aid Institutions providing legal aid for PwDs, (b) Institutions concerned with persons with disabilities, and (c) PwDs and/or their parents /accompaniments of PwDs obtained information that only $22.2 \%$ of the 275 respondents from Medan, Binjai and Deli Serdang stated that they had ever had legal problems in their daily lives.

Moreover, even if PwDs have a desire to get assistance related to legal issues involving them, assistance is expected to come from (a) 54\% Families, (b) 9.5\% Village Heads/Lurah, (c) 8\% Police, (d) 21.2\% Legal Aid Organizations, or (d) $<8 \%$ to institutions where PwDs are.

These two points are a challenge for online legal aid application developers, considering that the survey conducted was asked about what information should be available on online legal aid applications, the answers collected were: (1) Information on OBH/LBH located in sub-districts/districts with disabilities persons with 
disabilities, (2) Information on legal assistance provided by $\mathrm{OBH} / \mathrm{LBH}$, (3) There is a complaint column that can be filled in by PwDs, (4) Information on legal steps that will be provided by $\mathrm{OBH} / \mathrm{LBH}$, (5) Accommodation costs for the complainant /victim, (6) Legal assistance who is willing to do as a pick-up system. “...as PwDs, I don't always have access to good mobility when I go to where the institution is located. So, for example, if the application exists, I can submit a complaint online and the follow-up, if possible, is where the legal aid agency comes to the domicile of the person with disability" (N, 45 years), (7) It is necessary to include what constitutes the Law on disability regulation itself. Because maybe some people have not realized that the need for reporting or other legal processes is strengthened by existing regulations so that when carrying out legal processes there is no misunderstanding for people with disabilities. (8) Information about the LBH, it would be better if the members of the $\mathrm{LBH}$ are local persons where the $\mathrm{LBH}$ exists so that the handling/assistance to the community becomes more effective and fast, (9) Certainty of assistance to victims without any elements another. (10) Contact numbers for complaints services that are easily accessible and on time, as well as service centers and information can reach remote villages, (11) Effects of reporting for the complainant or victim, (12) No need to leave the house, Legal Aid Institution Party Come to the Reporting House to help until the problem is resolved without consuming a large amount of money, and (13) Column reviews or testimonials from application users and $\mathrm{OBH}$.

\section{CONCLUSION AND RECOMMENDATION}

Based on the description above, it can be concluded that (a) There are legal opportunity for PwD in accessing the legal aid services since Indonesia has legal provision of online legal assistance for PwDs. (b) There is not yet any platform used to provide online legal aid to PwDs. As suggestion, (a) Indonesia need to develop an online legal aid for PwDs. (b) Online legal aid for PwD in the form of Android application is an option based on easy access and low cost.

\section{ACKNOWLEDGMENTS}

We would like to thank the Research and Service Institute of Universitas Sumatera Utara who supported the authors to implement research program through TALENTA Universitas Sumatera Utara research scheme of Fiscal Year 2021 based on the Rector Letter Number: 496/UN5.2.3.1.R/PPM/SPP-TALENTA USU/2021 Dated on 18 June 2021.

\section{REFERENCES}

[1] Yahya Harahap, Pembahasan dan Penerapan KUHAP, Edisi Kedua Cet. 11, Sinar Grafika, Jakarta, 2009, hlm. 344
[2] Bambang Sunggono dan Aries Harianto, Bantuan Hukum dan Hak Asasi Manusia, Mandar Maju, Bandung, 1994, hlm. 10

[3] Dewi, A. A. I. A. A. (2018). Aspek Yuridis Perlindungan Hukum Dan Pemenuhan Hak Penyandang Disabilitas. Pandecta Research Law Journal, 13(1), 50-62.

[4] Undang-Undang Nomor 16 Tahun 2011 tentang Bantuan Hukum

[5] Siti Nurhayanti, "Kesetaraan Di Muka Hukum Bagi Penyandang Disabilitas, Jurnal Hukum Syari'ah STAIN Kediri, Vol. 14, Nomor 1 Tahun 2016, hlm. 101

[6] Helen Intania Surayda, “Akses Bantuan Hukum Berkeadilan Bagi Penyandang Disabilitas Korban Kekerasan Seksual”, E-Prosiding Seminar Nasional Hasil Penelitian, Lembaga Penelitian dan Pengabdian Kepada Masyarakat Universitas Semarang Semarang, 24 Agustus 2021, ISBN : 978623-7986-22-5

[7] Rosmalinda, R., Arif, A., \& Mardiyah, A. (2018, October). Pendampingan Hukum Bagi Penyandang Disabilitas di Kota Medan dan Binjai. In Talenta Conference Series: Local Wisdom, Social, and Arts (LWSA) (Vol. 1, No. 1, pp. 199-202)

[8] Chalil, D., Sidique, S. F., Barus, R., Abdul Hadi, A. H. I., Khaliqi, M., \& Fatoni, M. I. (Eds.). (2018, August). Legal aid for person with disabilities in access to justice. In E3S Web of Conferences (Vol. 52, p. 00040). EDP Sciences

[9] Mohamad, I. R., Idji, R. A., \& Napu, R. (2021). Urgensi Penyelenggaraan Bantuan Hukum Kepada Penyandang Disabilitas Di Kabupaten Gorontalo. Akademika, 9(1), 29-40.

[10] Malinda Anggun, Ekha Nurfitriana, dan M. Yasin Al Arif", "Bantuan Hukum terhadap Kaum Difabel Korban Tindak Pidana Upaya mewujudkan Acces to Justice”, Jurnal Hukum IUS QUIA IUSTUM No. 3 Vol. 21 Juli 2014: 465 - 484

[11] Peraturan Pemerintah Republik Indonesia Nomor 39 Tahun 2020 Tentang Akomodasi Yang Layak Untuk Penyandang Disabilitas Dalam Proses Peradilan- Government Regulation of the Republic of Indonesia Number 39 of 2020 concerning Adequate Accommodation for Persons with Disabilities in the Judicial Process 